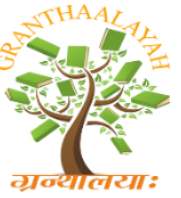

INTERNATIONAL JOURNAL OF RESEARCH GRANTHAALAYAH

A knowledge Repository

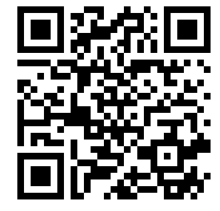

Social

\title{
GAME-BASED LEARNING ACTIVITIES IN TEACHING GRADE 7 SCIENCE
}

\author{
Jennifer D. Makalintal ${ }^{1}$, Dr. Nerrie E. Malaluan ${ }^{2}$ \\ ${ }^{1}$ Batangas State University, College of Teacher Education Rizal Avenue Batangas City, \\ Philippines
}

\begin{abstract}
Game - based learning is a process of inquiry that requires asking questions, observing, data exploration and data manipulation. It requires learning to apply and generalize scientific knowledge. Creating such learning environment requires engaging learners in different games. Active engagement in learning activities develops conceptual understanding and motivates students to seek further information.

The study described the game - based learning activities in teaching science as assessed by science teachers relative to motivation, application, feedback and reinforcement. It also analyzed significant differences in the teachers' assessments on the game - based activities according to profile variables. The extent by which the learning competencies were achieved and the constraints met using game - based learning activities were determined.

The descriptive method was used with the questionnaire as the main instrument to gather important data complimented by interview. Respondents were 35 science teachers in and the statistical tools used were weighted mean, frequency, t-test and F-test were the statistical tools used in this study. The findings revealed that majority of secondary science teachers in Oblate Schools were female, single, early adult with bachelor's degree. The science teachers strongly agreed that game - based learning activities utilized in application component. There is a significant difference between the descriptions of game - based learning activities when grouped according to age. The learning competencies in Biology and Physics are achieved to a moderate extent but slightly achieved in Earth Science and Biology. Insufficient materials and individual differences of the students were constraints met by science teachers.
\end{abstract}

Keywords: Game-based Learning; Game-based learning activities; Motivation; Application; Feedback; Reinforcement

Cite This Article: Jennifer D. Makalintal, and Dr. Nerrie E. Malaluan. (2019). "GAME-BASED LEARNING ACTIVITIES IN TEACHING GRADE 7 SCIENCE." International Journal of Research - Granthaalayah, 7(5), 256-277. 10.29121/granthaalayah.v7.i5.2019.845. 


\section{Introduction}

Science education cultivates students' curiosity about the world and enhances scientific thinking. Through the inquiry process, students will recognize the nature of science and develop scientific knowledge and science process skills to help them evaluate the impacts of scientific and technological development. This prepares students to participate in public discourse in sciencerelated issues and enable them to become life-long learners in science and technology.

Science Education differs significantly from the existing History and Philosophy of Science, and Science Technology Society movements in K-12 reform, it approaches science from a critical perspective and acknowledges that teaching science is inherently political. When student learning is geared toward what can be easily tested as it tends to be in high school science curricula, discrete, testable knowledge is privileged and there is no motivation to encourage students to be active, critical thinkers. The emphasis of science education is to enhance students' scientific literacy through investigative activities that involve planning, measuring, observing, analyzing data, designing and evaluating procedures, and examining evidence. Learning science will enable the students to lead a fulfilling and responsible life by encouraging them to learn independently, deal with new situations, reason critically, think creatively, make informed decisions and solve problems.

Games-based learning (GBL) may be a suitable approach to address some of the problems associated with traditional approaches to teaching requirements collection and analysis as it is perceived as a highly engaging approach for learning at a supplementary level. Games and the distinctive culture that is associated with them are beginning to receive the attention they deserve from the students. Educators must provide more than one opportunity to learners if they are not successful in demonstrating important learning. Teachers' main task is to encourage the work and personal effort of each student as well as provide guidance in collaboration with parents.

Science teachers should find ways to lift barriers to student's learning. Game - based learning attempts to focus clearly and deliberately on student learning. Major time constraints are not ignored, but time is seen as a flexible resource rather than as a principal factor that controls access to learning. Understanding what makes for a successful approach to game-based learning is therefore particularly pertinent as a way to increase participation in science and technology. Game - based learning is designed to balance pedagogical requirements with an elusive fun-factor, meaning there must be balance of fun with learning concepts ${ }^{[1]}$.

The incorporation of games into education is often more effective than traditional teaching methods in enhancing learning motivation, active participation, and concentration among students. Game - based learning activities (GBLA) can be used to motivate students as well as help them develop skills, abilities and strategies. GBLA can attract the attention of a student, because it can arouse a student's perception through surprising events or inquiry and challenging problems to be solved ${ }^{[2]}$.

Steele ${ }^{[3]}$ cited that when other subjects, such as reading, or mathematics are embedded into a hands-on science activity, students may actually score better when tested on these skills than if the subject matter had been taught in a traditional way. Through games, there is a collaboration between a general education teacher and a special education teacher, appropriate modifications, 
such as overarching themes to units and flexibility in how students report what they learn, can be put into place, and lend scientific material accessible to every student.

Game based learning as a tool in science enhances creation of interest in the subject, real and scientific problems, perseverance, concentration, content mastery as well as visual skills, all of which are vital in the learning of science. This often is not achievable in the traditional classroom setting due to teacher and facilities limitation such as poor content mastery and inadequate quality and quantity of reference materials. If one can harness the potential of computer games in schools, student's science ability may improve tremendously. These game activities may be applied to the real - life situation of the students and then they will realize that teachers really do their job to give knowledge to the students.

Higgins et al. ${ }^{[4]}$ reached on the conclusion that using different games in secondary science is more effective than traditional method of teaching. The idea of using games to engage students in the process of active learning is not new. Over the past several years, educators have been increasingly incorporating various games into their teaching curriculum in an effort to create a fun and engaging learning environment for students. Although this can be very challenging, and time consuming, interactive, collaborative and competitive games tend to motivate and encourage student participation in the learning process.

Wexter et al. ${ }^{[5]}$ stated that gamification can add extrinsic motivation to make activities palatable, using scores and badges; gamification is said to provide environmental simulations. Self-effective and self-motivated learners can learn from such an environment, exploring to understand a particular concept. Games can be competitive in nature, others may simply allow students to work together as a class to solve a general problem where no one "wins" or "loses." Thus, support the learning process by encouraging experimentation, hypothesis testing and synthesis which are all higher-level thinking skills. Game - based learning concepts and approaches have high learning value developing critical thinking, group communication, debate and decision making. However, game - based need good game design elements of learning and engagement should be taken in consideration.

Evidently, games have appeal due to their competitive element. In games and structured activity, participants are actively involved and use all their senses which increases their energy and participate to learn a concept or idea, increase self-awareness, provide practice for risk - taking, or develop a specific skill. Activity games help students to become good and productive citizens of their own selves and for the country. They will not be able to be as one, if they will not be trained and be equipped with what is due to them to make them real hopes of the future. This kind of activity games may serve as the training ground and foundation of molding them as the future leaders in the next generations.

Game-based learning activities on the developments, the gamification is a process that needs to be thought of properly and carried out systematically for a longer time frame. It cannot be assumed that results via gamification are an instant success. Gamification can create a state of flow in a person that enables or pushes one to be in the zone to carry out certain tasks. Meanwhile the aspects of mastery, will exist if the users can get immersed in the gamified system thus is willing to repeat the tasks given. This is so that they are used to it or that they become expert in the system; end 
route to achieving the goals intended. A person will continue carrying out the tasks until they have achieved the intended goal that allows the users to feel complete or satisfied. It allows the users to feel in control of how or why they play the gamified system, thus not feel coerced by the gamified system. This is a key element as one important element of any games is fun. Besides that, it is concluded that gamification can induce motivations on a person via the game mechanics; and not the behavior ${ }^{[6]}$.

For Lazares ${ }^{[7]}$, game - based activities may be a good tool to promote learners to actively participate in learning activities. The game - based learning could be the best way to trigger student's learning motivation. In addition, it has been reported that a game - based learning approach might provide a good chance to stimulate students' abstract thinking during the process of cognitive development, and further foster their higher order thinking ability. There are opportunities with new and emerging technologies for providing effective coaching in an advance game environment.

The basic reason for learning via games is that rather than using paper-and-pencil tests to assess student performance, educators using learning game activities often employ authentic performance and student-centered assessments. These assessments seek to connect assessment and instruction and involve students in examining the process and products of learning. In performance assessment, students reveal their skills, problem-solving abilities, and knowledge and understanding of science by creating and making things, developing projects, solving problems, producing written products, responding to simulations, giving presentations, conducting investigations, and designing and performing experiments. For example, as part of a unit on water pollution, students can perform a variety of activities and experiments using local water samples. These activities can then be assessed by having students present their findings to a local community group and/or by creating a web page summarizing their results. The different activities may use computers and internet. The students are very active when teachers use games via internet and computers ${ }^{[8]}$.

Five levels of application and key components of interactive games may be applied in science lessons that are delineated to help educators determine the scope and purpose of instructional games and to set a context for the posited methods. Then, a basic games development process is characterized, including discussions of how educators can apply their knowledge of the subject matter, educational context, and pedagogy during the process to optimize game-based learning. Science lesson is also an important consideration when defining game levels. As a player progresses through levels, the degree of difficulty may remain constant, increase linearly, or follow an s-curve, with the degree of difficulty remaining relatively flat at the beginning and end, but increasing exponentially during the middle ${ }^{[9]}$.

Thomberg ${ }^{[10]}$ pointed out that in the Philippines the problem of teachers teaching at the junior high school level in villages is the inability of teachers to use student-centered instructional strategies instead of teacher-centered ones. Teachers in schools taught science using basically lecture methods based on textbooks. Most teachers also faced challenges in language policy adopted by different schools, where the medium of instruction for science is English. Science teachers including science teachers were of the view that the use of English as a medium affect students' performance as the transition is poor and most students are left in the state of confusion. 
Apparently, students are now in the cyberspace age and innovation in teaching is indeed a demand for a transformation in the educative process. Teaching is not an easy task and learning must pave the way to produce productive citizens and successful individuals in the future.

\section{Materials and Methods}

The study used descriptive method of research utilizing questionnaire as key instrument and the used of interview as supplemental sources of information. There were 35 Grade 7 Science teachers who served respondents from 9 schools in Oblates. Frequency/percentage, weighted mean and ttest were the statistical tools utilized in this study. No sampling method was used in the study.

\section{Results and Discussions}

\subsection{Profile of Grade 7 Science Teachers}

The profile of Grade 7 Science teachers in terms of age, sex, civil status, educational attainment, and trainings attended in Science was determined in this study. Results are shown in Tables 1 to 5 .

\subsubsection{Age.}

The age of the respondents was one of the most important characteristics in understanding their views about the particular problems and it indicates level of maturity of individuals in that sense age becomes more important to examine the response. The profile of Grade 7 science teachers as to their age is presented in Table 1.

Table 1: Profile of Grade 7 Science Teachers in Terms of Age

\begin{tabular}{|l|l|l|}
\hline Age & Frequency & Percentage \\
\hline 25 years and below & 14 & 40.00 \\
\hline $26-35$ & 11 & 31.43 \\
\hline 56 and above & 10 & 28.57 \\
\hline Total & $\mathbf{3 5}$ & $\mathbf{1 0 0}$ \\
\hline
\end{tabular}

As contained on the table, most or 14 respondents or 40.00 percent were 25 years and below. Eleven science teachers or 31.43 percent were on the age bracket of 26-35 years old, and ten teachers or 28.57 percent were 56 years old and above. This is an indication that the teachers were on their late 20's and they may have considered as professionals and may have acquired 3 years in teaching science. This finding affirms the concept of Mift ${ }^{[11]}$ that teaching field is mostly dynamic for teachers ages 20 to 40, they particularly doing the utmost level of performance in those ages.

\subsubsection{Sex}

Science teaching is a field handled by man and woman in junior high school. The profile of the respondents in terms of sex is contained in Table 2. 
Table 2: Profile of Grade 7 Science Teachers in Terms of Sex

\begin{tabular}{|l|l|l|}
\hline Sex & Frequency & Percentage \\
\hline Male & 7 & 20.00 \\
\hline Female & 28 & 80.00 \\
\hline Total & $\mathbf{3 5}$ & $\mathbf{1 0 0}$ \\
\hline
\end{tabular}

As shown in the table, out of 35 science teachers, majority or 28 of them or 80.00 percent were female, and seven respondents or 20.00 percent were male. The data affirms that many science teachers were female because the teaching profession is still dominated by women.

\subsubsection{Civil Status}

This study explores if teacher's status has something to with their application of game - based activities in science teaching. Table 3 reflects the profile of Grade 7 teachers in terms of their civil status.

Table 3: Profile of Grade 7 Science Teachers in Terms of Civil Status

\begin{tabular}{|l|l|l|}
\hline Civil Status & Frequency & Percentage \\
\hline Single & 22 & 62.86 \\
\hline Married & 13 & 37.14 \\
\hline Total & $\mathbf{3 5}$ & $\mathbf{1 0 0}$ \\
\hline
\end{tabular}

From the table, it can be seen that 22 respondents or 62.86 percent were single and 13 of them or 37.14 percent were married. Evidently, the finding reveals that most science teachers were single. As shared during the interview, being a teacher was one reason for being a single. The demand on activities and paper works did not give them time to focus on their personal needs like being married.

\subsubsection{Educational Attainment}

Teachers influence students through their interactions with them, especially in the classroom. Their educational level and experience may affect their ability to manage the science classroom efficiently and to promote student achievement. The profile of Grade 7 science teachers in terms of educational attainment is contained in Table 4.

Table 4: Profile of Grade 7 Science Teachers in Terms of Educational Attainment

\begin{tabular}{|l|l|l|}
\hline Degree & Frequency & Percentage \\
\hline Bachelor's Degree & 25 & 71.43 \\
\hline with Masteral units & 8 & 22.86 \\
\hline with Doctoral Units & 2 & 5.71 \\
\hline Total & $\mathbf{3 5}$ & $\mathbf{1 0 0}$ \\
\hline
\end{tabular}

It can be gleaned in the table that 25 science teachers or 71.43 percent were Bachelor of Secondary Education degree graduates. Eight of them or 23.86 percent had masteral units and two or 5.71 of the respondents earned doctoral units. The finding showed majority of Grade 7 science teachers were bachelor degree holders; however, some earned MA units and doctoral to upgrade themselves 
on the new trends in science education especially relative to science instruction. It was also a way for them to be promoted. As revealed by the science teachers during the interview, it was very hard for them to pursue masteral degree because of time and financial concerns.

\subsubsection{In-Service Training Activities}

Teachers are essential resource 'for successful learning. Well - trained and skilled science teacher will be able to enhance not only the quality of their teaching but competence and performance of their students. In equipping them towards these, in - service training is vitally important. The seminars/trainings attended by Grade 7 science teachers is presented in Table 5.

Table 5: Profile of Grade 7 Science Teachers in terms of In-Service Training Activities

\begin{tabular}{|c|l|l|}
\hline In-Service Training Activities & Frequency & Percentage \\
\hline $0-2$ Not Active & 8 & 22.86 \\
\hline $3-5$ Active & 27 & 77.14 \\
\hline Total & $\mathbf{3 5}$ & $\mathbf{1 0 0}$ \\
\hline
\end{tabular}

As depicted in Table 5, out of 35 respondents, 27 or 77.14 were active in attending trainings and eight or 22.86 percent were not active in attending trainings. It can be deduced from the table that majority of the science teachers were active. As revealed from the interview conducted, teachers attended trainings because they need the continuing professional development units (CPD) to renew their license. Moreover, they know that these seminars/trainings will help them create an effective learning environment, improve their teaching-learning capacities, keep them updated on modern instructional devices and inspire them to become better teachers in the modern world.

\subsection{Descriptions of Game-based Learning Activities}

Game - based learning activities can support learning environment where teachers and students are confident and proficient users of games. The status of integration of game - based learning activity in delivering the different components such as motivation, application, feedback and reinforcement was also assessed in this study. These are presented in Tables 6 to 9 .

\subsubsection{Motivation}

Integration of games into teaching and learning activities is a challenge for many reasons. It may provide interesting formats and add motivation to various activities Table 6 shows the description of game-based learning activities in relation to motivation.

Table 6: Descriptions of Game - based Learning Activities in relation to Motivation

\begin{tabular}{|l|l|l|}
\hline ITEMS & WM & VI \\
\hline Encourage open communication and free thinking for the students & 3.66 & SA \\
\hline Direct and sustain a good behavior of the students & 3.60 & SA \\
\hline Enhance the cognitive processing skills of the students & 3.54 & SA \\
\hline Improve persistence and effort for the lesson & 3.49 & A \\
\hline Help student build self-esteem in learning & 3.49 & A \\
\hline
\end{tabular}




\begin{tabular}{|l|l|l|}
\hline $\begin{array}{l}\text { Reinforce courage, curiosity, and confidence of the student to accomplish their } \\
\text { goals }\end{array}$ & 3.49 & A \\
\hline Enable learner to process information more deeply & 3.43 & A \\
\hline Emphasize participation and interpersonal relations within their classmates. & 3.43 & A \\
\hline Initiates interactive learning experience among learners & 3.43 & A \\
\hline Escalates opportunities for students to group easily the lesson & 3.43 & A \\
\hline Facilitates hands-on-minds on priming activity for students & 3.43 & A \\
\hline Energize students to learn from the lesson & 3.40 & A \\
\hline Create a positive mindset for the students toward learning & 3.37 & A \\
\hline Establish a good introduction for a new lesson & 3.37 & A \\
\hline Engage students in an enthusiastic learning activities & 3.37 & A \\
\hline Help learners to attain the learning competencies in different ways & 3.34 & A \\
\hline Excite student's interests in dealing with certain lesson & 3.34 & A \\
\hline Composite Mean & $\mathbf{3 . 4 5}$ & A \\
\hline
\end{tabular}

Legend: WM=Weighted Mean

SA= Strongly Agree

VI= Verbal Interpretation

A $=$ Agree

The respondents strongly agreed that game - based learning activities encouraged open communication and free thinking for the students gaining a weighted mean of 3.66. When the lines of communication are open, the students feel comfortable with other students and they will be able to perform well a specific task. This finding has something to do with the idea of Jandonero ${ }^{[12]}$ that there is a need to know how to think instead. This can be initiated through various game activities, alternative assessment methods and new ways of teacher's preparation.

The highest weighted mean of 3.60 indicates the teachers strongly agreed that utilization of gamebased learning activities could direct and sustain good behavior of the students. It is necessary for the teachers to motivate the students for better learning and to catch their attention in a class discussion.

Least rated by the OSJ science teachers as shown in weighted mean of 3.34, was that motivation excite students' interests in dealing with certain lesson. Presumably, the teachers found it difficult to engage in every activities using games. This finding conforms with De Guzman ${ }^{[13]}$ that problems associated with game activities are lack of motivation, not very interesting/boring, little encouragement of self-learning, less meaningful and no continuity among lessons: as it is most students think that science is difficult, complicated and confusing subject because it involves formulas and calculations.

To sum up, the respondents agreed that the game - based learning activities can be very helpful to promote student's interest as indicated in the composite mean of 3.45. This affirms that most of the students were motivated to study science lessons because of the different games integrated with the lessons. As Lardizabal ${ }^{[14]}$ posited different activities in science arouse students' interest which can lead in developing the desirable traits.

\subsubsection{Application}

The challenge confronting the educational system is how to transform the curriculum and teaching learning process to provide students with the skills to function effectively in this dynamic, 
information-rich, and continuously changing environment. To meet these challenges, learning institutions must apply new technologies and appropriate tools for learning and improve activities. Table 7 shows the status of application of game-based learning activities.

Table 7: Description of Game-based Learning Activities in relation to Application

\begin{tabular}{|l|l|l|}
\hline ITEMS & WM & VI \\
\hline Encourage students to develop their skill continuously and steadily overtime & 3.57 & SA \\
\hline Develop critical thinking and creativity of student & 3.57 & SA \\
\hline $\begin{array}{l}\text { Develop learners who are self - directed and self - motivated to achieve the } \\
\text { outcome that they want }\end{array}$ & 3.57 & SA \\
\hline Allow learner to enhance their competence towards learning & 3.51 & SA \\
\hline Provide learners opportunity to play variety of games & 3.49 & A \\
\hline Enhance the retention of the students & 3.49 & A \\
\hline Enable learners to learn from their mistakes and become a more confident player & 3.43 & A \\
\hline Composite Mean & $\mathbf{3 . 5 2}$ & SA \\
\hline
\end{tabular}

It can be seen in the table that science teacher strongly agreed that games encouraged students to develop their skills continuously and steadily overtime, developed their critical thinking and creativity and developed them to be self - directed and self - motivated to achieve the outcome that they want. These items obtained the same weighted mean of 3.57. These activities can be prepared throughout almost any competencies, to introduce learners, stimulate discussions, increase interaction, challenge presumption and achieve diverse course objectives. This finding supports the study of Tatlonghari ${ }^{[15]}$ which revealed that the use of interactive activities lite games as an integral component with other methods and techniques was found effective than just using the traditional approach of teaching.

It was likewise strongly agreed that game - based activities allowed learner to enhance their competence towards learning as revealed by the respondents. This obtained a weighted mean of 3.51. This means that in the fast - paced world of game - based learning activities to make a course exciting are always changing, and course content can and should be updated quickly to give the students the very latest information. They engage learners to different knowledge to make them more confident learners. It affirms with the concept of Steele ${ }^{[3]}$ that games can enhance the interest of the students in a specific subject. It can harness the potential of the student to improve their ability to reach and achieved different competencies.

Lastly, assessed low by teachers was game - based activities enabled learners to learn from mistakes and made them more confident players reflected in weighted mean of 3.43. This game builder includes variety of games which may be modified and formulated by teachers. The game - based learning activities can be used by instructors to accomplish a variety of goals, such as introducing learners to one another, becoming confident player, increasing participation, or encouraging learners to develop learning relationships throughout the subjects. It conforms with Higgins's ${ }^{[4]}$ statement that games can motivate and encourage student participation in the learning process, although games can be very challenging, time consuming, interactive, collaborative and competitive activities. 
To sum up, the composite mean of 3.52 indicates that the respondents confirmed that game - based learning activities play a vital role in high quality activities in the learning and teaching process. Conclusively, it can be said that the advances in technology can open new possibilities for teachers to educate their learners, giving potential for innovative ways to encourage them to become more engaged in their schooling. As result show, majority of the teachers strongly agreed that application of game - based learning activities affected their behavior and communication. The finding supports the study of Brunice ${ }^{[16]}$ that game-based learning activities are an ideal tool for creating visual models and simulations and ideas and even distance learning that cannot be created in traditional teaching.

\subsubsection{Feedback}

Table 8 shows the description of game-based learning activities in relation to feedback.

Table 8: Description of Game-based Learning Activities in relation to Feedback

\begin{tabular}{|l|l|l|}
\hline ITEMS & WM & VI \\
\hline Motivate and energize learners to perform better & 3.43 & $\mathrm{~A}$ \\
\hline Increase student's self-efficacy & 3.34 & $\mathrm{~A}$ \\
\hline Improve students' confidence, self-awareness, and enthusiasm for learning & 3.31 & $\mathrm{~A}$ \\
\hline Give purpose and feeling of belonging & 3.29 & $\mathrm{~A}$ \\
\hline Increase growth and happiness for the learners & 3.29 & $\mathrm{~A}$ \\
\hline Empower the best use of their productive hours in learning. & 3.29 & $\mathrm{~A}$ \\
\hline Optimize resources and maximize output satisfaction & 3.29 & $\mathrm{~A}$ \\
\hline Unlock self-reflection & 3.23 & $\mathrm{~A}$ \\
\hline $\begin{array}{l}\text { Help learners to get on track and serves as a guide to assist learner to know how } \\
\text { they and others perceive their performance }\end{array}$ & 3.14 & $\mathrm{~A}$ \\
\hline Composite Mean & $\mathbf{3 . 2 9}$ & $\mathrm{A}$ \\
\hline
\end{tabular}

Legend: WM=Weighted Mean

$\mathrm{VI}=$ Verbal Interpretation

A $=$ Agree

As agreed on by the teachers - respondents, use of game - based learning activities increased students' self-efficacy which obtained a weighted mean of 3.34. Undoubtedly, the OSJ science teachers agree that they were able to teach to the students how to find the answers when encountering difficulties during the learning process, which positively affects their learning outcomes. Gaming strategies have good potential for decreasing the scientific anxiety of students. Carin ${ }^{[17]}$ pointed out that applying games in the lesson provides learners to learn their own and to present the ideas that they want. Teachers agreed that to helped learners to get on track and guided students to know how they and others perceive their performance.

The composite mean of 3.29 shows that the OSJ science teachers agreed on to the descriptions of game-based learning activities in teaching Grade 7 science in terms of feedback. This is an indication that the teachers were capable and have the ability to teach science which leads to meaningful learning with the use of games in their science instruction. This, however, needs careful, meticulous preparations of all that are necessary for the success of a game which is the responsibility of the teacher. 


\subsubsection{Reinforcement}

This plays a key role in the condition of operant behavior and acquisition of learning. Table 9 shows the description of game-based learning activities as a reinforcement tool.

Table 9: Description of Game-based Learning Activities in relation to Reinforcement

\begin{tabular}{|l|l|l|}
\hline ITEMS & WM & VI \\
\hline Increase the probability of the students to response repeatedly & 3.51 & SA \\
\hline Emphasize the positivity of the action & 3.46 & $\mathrm{~A}$ \\
\hline Give an appreciative comment that immediate follow any good deed to the learners & 3.46 & $\mathrm{~A}$ \\
\hline Send learners to real life lesson & 3.46 & $\mathrm{~A}$ \\
\hline Make the student aware of where their strengths lie & 3.46 & $\mathrm{~A}$ \\
\hline Encourage positive actions that can have long-standing effects to the students & 3.46 & $\mathrm{~A}$ \\
\hline Encourage the students to have deep understanding of the lesson & 3.43 & $\mathrm{~A}$ \\
\hline Encourage repetition of good deeds committed by the students & 3.40 & $\mathrm{~A}$ \\
\hline Enhance the memory stimulus of the students & 3.40 & $\mathrm{~A}$ \\
\hline $\begin{array}{l}\text { Provide opportunity to reveal a hidden talent of the students that exhibits desired } \\
\text { behavior }\end{array}$ & 3.37 & $\mathrm{~A}$ \\
\hline Help the student understand the do's and don'ts better & 3.37 & $\mathrm{~A}$ \\
\hline Increase the desired behavior of the students & 3.34 & $\mathrm{~A}$ \\
\hline Provide further instruction for the students to learn the lesson & 3.31 & $\mathrm{~A}$ \\
\hline Composite Mean & $\mathbf{3 . 4 2}$ & $\mathbf{A}$ \\
\hline
\end{tabular}

Legend: WM=Weighted Mean $\quad$ VI= Verbal Interpretation $\quad$ SA= Strongly Agree $\quad A=$ Agree

As manifested in the table, use of game - based learning activities increased the probability of the students to respond repeatedly which was strongly agreed by the highest weighted mean of 3.51 . This implies that games increase students' interest and decreases the chance of boredom. In relation to this, students get more motivated and immersed into games in comparison to other classroom activities. Game based learning is novel and an interactive approach to teaching and learning and can be considered complete learning package for learners irrespective of their age. It was disclosed that providing further instruction for the students to learn the lesson were agreed on by the respondents. This got a weighted mean of 3.31. This indicates that giving more instruction will lead to increased students' performance. It assists science teachers in persuading or motivating their students to perform and understand complex to simple topics with ease in less time. Gee ${ }^{[6]}$ affirmed that game-based learning is a very powerful in engaging learners' attention for a longer span of time. These do not only things in the real world into games but also use the mechanics and apply them to the real world.

The composite mean of 3.42 shows that the OSJ science teachers agreed that game-based learning activities in teaching Grade 7 science in terms of reinforcement. This is an indication that the teachers were very resourceful, because some content of the subjects that cannot be seen on textbook, they look for another source and that is through the different game-based learning activities. 


\subsection{Difference on the Description of Game - based Learning Activities when grouped according to Profile Variables}

This study determined the difference in the responses of science teachers on the motivation, application, feedback and reinforcement as grouped according to profile variables. Table 10 shows the difference on assessment on the description of game - based learning activities according to age.

As manifested in the table, there was no significant difference in the description of game - based learning activities as to motivation when grouped according to age was computed in the F-value of 0.061 with a p-value of $0.980(\geq 0.05)$. As such, the null hypothesis was accepted and there is no significant difference on the description of game - based learning activities in terms of motivation when the respondents are grouped according to age. Science teachers with different age are more likely to have similar description of game - based learning activities in terms of motivation.

Table 10: Difference on the Description of Game-based Activities when grouped according to

Age

\begin{tabular}{|l|l|l|l|l|}
\hline Variable & $\mathbf{F}_{\mathbf{c}}$ & $\mathbf{p}$ - value & Decision on Ho & Interpretation \\
\hline Motivation & 0.061 & 0.980 & Do not Reject & Not Significant \\
\hline Application & 2.948 & 0.048 & Reject & Significant \\
\hline Feedback & 1.334 & 0.281 & Do not Reject & Not Significant \\
\hline Reinforcement & 4.045 & 0.015 & Reject & Significant \\
\hline
\end{tabular}

$$
\alpha=0.05
$$

In the description of game - based learning activities in terms of application, result show the computed F-value of 2.948 with a p-value of $0.048(\geq 0.05)$, which indicates that the null hypothesis is rejected. This means that there is a significant difference on the description of game - based learning activities in terms of application when grouped according to age. This means that older science teacher cannot thoroughly apply different games in lesson unlike those who are not yet old.

There was no significant difference on the description of game - based learning activities in terms of feedback when grouped according to age. The null hypothesis is accepted with a computed Fvalue of 1.334 with a p-value of $0.281(\geq 0.05)$. It indicates that there is no impact on the age in the description of game -based learning activities in terms of feedback.

The table indicates that the null hypothesis is rejected and there is a significant difference in the description of Game - based Learning Activities in terms of reinforcement when grouped according to age. It is showed with the F-value of 4.045 with a p-value of $0.015(\geq 0.05)$. This shows that old science teachers cannot reinforce games in the lessons.

Table 11 presents the differences in the description of Game - based learning activities when the respondents are grouped according to sex. In the description of Game - based Learning Activities in terms of motivation, the table shows that computed mean t-values of 0.679 with a $\mathrm{p}$-values of $0.519(\geq 0.05)$ which indicates that the null hypothesis is accepted. This means that there is no 
significant difference on the description made by science teachers on their game - based learning activities in terms of motivation when grouped according to sex.

Table 11: Difference on the Description of Game-based Activities when grouped according to

\begin{tabular}{|c|c|c|c|c|}
\hline \multicolumn{5}{|c|}{ Sex } \\
\hline Variable & $\mathbf{t}_{\mathbf{c}}$ & p-value & Decision on $\mathrm{H}_{0}$ & Interpretation \\
\hline Motivation & 0.679 & 0.519 & Do not Reject & Not Significant \\
\hline Application & -0.725 & 0.473 & Do not Reject & Not Significant \\
\hline Feedback & -1.204 & 0.237 & Do not Reject & Not Significant \\
\hline Reinforcement & -0.894 & 0.378 & Do not Reject & Not Significant \\
\hline
\end{tabular}

The table shows the computed mean t-values of -0.725 with a p-values of $0.473(\leq 0.05)$ in the description of Game - based learning activities in terms of application which indicates that the null hypothesis is accepted. This means that there is no significant difference on the description made by science teachers on their game - based learning activities in terms of application when grouped according to sex. Male and female science teachers are more likely to have similar description of Game - based activities in terms of application.

In the description of Game - based learning activities in terms of feedback, the table shows that computed mean t-values of -1.204 with a p-values of $0.237(\leq 0.05)$ which indicates that the null hypothesis is accepted. This means that there is no significant difference on the description made by science teachers on the game - based learning activities in terms of feedback when grouped according to sex.

The table indicates that the null hypothesis is accepted and there is no significant difference in the description of Game - based learning activities in terms of reinforcement when grouped according to sex. It is showed with the $t$-values of -0.894 with a p-values of $0.378(\leq 0.05)$.

Table 12 presents the difference in the description of game - based activities when grouped according to Civil Status.

Table 12: Difference on the Description of Game-based Activities when grouped according to Civil Status

\begin{tabular}{|c|c|c|c|c|}
\hline Variable & $\mathbf{t}_{\mathrm{c}}$ & p - value & Decision on $\mathrm{H}_{0}$ & Interpretation \\
\hline Motivation & 0.902 & 0.374 & Do not Reject & Not Significant \\
\hline Application & -1.073 & 0.291 & Do not Reject & Not Significant \\
\hline Feedback & 0.277 & 0.783 & Do not Reject & Not Significant \\
\hline Reinforcement & -0.023 & 0.791 & Do not Reject & Not Significant \\
\hline
\end{tabular}

As reflected in the table, the difference of description of game - based learning activities when grouped according to civil status showed no significant differences in terms of motivation, application, feedback and reinforcement. The p-value, 0.374 , of the computed t-value of 0.902 was greater than the level of significance of 0.05 . Consequently, the null hypothesis was accepted. 
The description of game - based learning activities when grouped according to civil status in terms of application. It was reflected in the computed t-value of -1.073 with p-value of $0.291(\leq 0.05)$. The null hypothesis was therefore accepted. Most of the students motivated when teachers used games in lesson. They were really understood the lesson and the teacher can catch the attention of the student by using it.

Similar difference was depicted on the description of game - based learning activities in terms of feedback. This was supported by the computed t-value of 0.227 and it had a p-value of 0.783 which has greater than the level of significance 0.05 . This led the acceptance of the null hypothesis. Lastly the difference in the description of game - based learning activities when grouped according to civil status in terms of reinforcement. The computed t-value of -0.023 with a p-value of 0.791 $(\leq 0.05)$, showed that the null hypothesis is accepted. Most teachers are very eager to give their best for the students. They give their full effort to reinforce students to learn and make the best output for a specific lesson.

Table 13 presents the difference in the description of game - based activities when grouped according to educational attainment.

Table 13: Difference on the Description of Game-based Activities when grouped according to Educational Attainment

\begin{tabular}{|l|l|l|l|l|}
\hline Variable & $\mathbf{F}_{\mathbf{c}}$ & $\mathbf{p}-$ value & Decision on Ho & Interpretation \\
\hline Motivation & 0.095 & 0.910 & Do not Reject & Not Significant \\
\hline Application & 1.386 & 0.265 & Do not Reject & Not Significant \\
\hline Feedback & 0.076 & 0.927 & Do not Reject & Not Significant \\
\hline \multicolumn{2}{|c|}{$\alpha=0.05$} & Do not Reject & Not Significant \\
\hline
\end{tabular}

As gleaned in the table, the difference in the description of game - based learning activities in terms of motivation when grouped according to educational attainment was computed in the Fvalue of 0.095 with a p-value of $0.910(\geq 0.05)$. It shows that the null hypothesis is accepted and there is no significant difference on the description of game - based learning activities in terms of motivation when the respondents are grouped according to educational attainment. Science teachers with different educational attainment are more likely to have similar description of game - based learning activities in terms of motivation. Further, it can be inferred that the level of education achieved by science teachers has no direct impact on the motivation in game - based learning activities.

In the description of game - based learning activities in terms of application, result show the computed F-value of 1.386 with a p-value of $0.265(\geq 0.05)$, which indicates that the null hypothesis is accepted. This means that there is no significant difference on the description of game - based learning activities in terms of application when grouped according to educational attainment. Science teachers with different educational attainments are likely to have similar description of game - based learning activities in terms of application.

There is no significant difference on the description of game - based learning activities in terms of feedback when grouped according to educational attainment. The null hypothesis is accepted 
with a computed F-value of 0.076 with a p-value of $0.927(\geq 0.05)$. It indicates that there is no impact on the educational attainment in the description of game -based learning activities in terms of feedback.

The table indicates that the null hypothesis is accepted and there is no significant difference in the description of Game - based Learning Activities in terms of reinforcement when grouped according to educational attainment. It is showed with the F-value of 0.808 with a p-value of 0.454 $(\geq 0.05)$. It is very important for the teachers to graduate in any degree like masteral or doctoral degree, because they can use what they have learned from that in imparting knowledge to the students and also, they can execute correctly the activities like games in teaching students.

\subsection{Extent of Achievement of Learning Competencies in Science Areas}

The knowledge on how to engage students is important because it is necessary and relevant to helping educators create a school - wide community of learning. In order to create an equitable classroom, teachers felt that it was necessary that students come to their own conclusions of the importance of their participation in class. Also, in order for students to learn, they have to have prior knowledge to build upon. Achievable learning competencies are necessary component of every single day of a student's education. The extent of achievement of learning competencies in carrying out the games in the four components of grade 7 science are presented in Tables 14 to 17.

\subsubsection{Earth Science}

Table 14 presents assessment of the teachers in the achieved learning competencies of students in carrying out the activities in Earth Science.

Table 14: Learning Competencies in Earth Science

\begin{tabular}{|l|l|l|}
\hline ITEMS & WM & VI \\
\hline $\begin{array}{l}\text { Recognize that soil, water, rocks, coal, and other fossil fuels are Earth's material } \\
\text { resources }\end{array}$ & 2.54 & ME \\
\hline Demonstrate how places on Earth may be located using a coordinate system & 2.51 & ME \\
\hline Show what causes change in the seasons in the Philippines using models & 2.51 & ME \\
\hline $\begin{array}{l}\text { Collect, record, and report data on the beliefs and practices of the community in } \\
\text { relation to eclipses }\end{array}$ & 2.51 & ME \\
\hline Describe ways of using Earth's resources sustainably & 2.49 & SE \\
\hline Explain how solar and lunar eclipses occur & 2.49 & SE \\
\hline $\begin{array}{l}\text { Relate the location of the Philippines with respect to the continents and oceans of } \\
\text { the world }\end{array}$ & 2.46 & SE \\
\hline Discuss how energy from the Sun enters the atmosphere & 2.43 & SE \\
\hline Describe the effects of certain weather systems in the Philippines & 2.40 & SE \\
\hline $\begin{array}{l}\text { Account for the occurrence of land and sea breezes, monsoons, and intertropical } \\
\text { convergence zone (ITCZ) }\end{array}$ & 2.37 & SE \\
\hline Explain how some human activities affect the atmosphere & 2.34 & SE \\
\hline Composite Mean & $\mathbf{2 . 4 6}$ & SE \\
\hline
\end{tabular}

Legend: WM=Weighted Mean $\quad$ VI= Verbal Interpretation $\quad \mathrm{ME}=$ Moderate Extent $\mathrm{SE}=\mathrm{Slight}$ Extent 
As manifested in the table, the assessment of the teachers in the achieved learning competencies of the students in recognizing that soil, water, rocks, coal, and other fossil fuels are earth's material resources were achieved to a moderate extent. This obtained the highest weighted mean of 2.54 among eleven items. It implies that science is an important discipline towards understanding the world. It conforms with the idea of Kegan ${ }^{[18]}$ that very effective for the students if they recognize those different resources or they can provide a plan to become involved and to interact with other students, thus leading to increased learning development.

Least rated by the teachers were the achieved learning competencies of the students in explaining by making model on how human activities affect the atmosphere. This got a weighted mean of 2.34 and also achieved by the students to slight extent. It seems that science teaching and learning is didactic and theoretical therefore students rarely engage in hands - on practical and activity work. As revealed by the science teachers during the interview making model was very hard for the students because they don't have enough time and money to buy the materials they need.

As a whole, the composite mean of 2.46 was an indication that the learning competencies in Earth Science are slightly achieved by the students as assessed by science teachers. Seemingly, the concepts earned by students in this component of science prepared them to tackle more abstract science concepts about earth and space in higher grade levels.

\subsubsection{Biology}

The experiences gained through different activities in each module will allow students to transform the information they obtain into a form that is able them to interpret on their own personal and community context. Table 15 reflects the response of the teachers in assessing the extent of achievement of learning competencies by the students in Biology.

Table 15: Learning Competencies in Biology

\begin{tabular}{|l|l|l|}
\hline ITEMS & WM & VI \\
\hline Describe the different ecological relationships found in an ecosystem & 2.66 & ME \\
\hline Predict the effect of changes in abiotic factors on the ecosystem & 2.66 & ME \\
\hline Describe the process of fertilization & 2.63 & ME \\
\hline $\begin{array}{l}\text { Predict the effect of changes in one population on other populations in the } \\
\text { ecosystem }\end{array}$ & 2.63 & ME \\
\hline Focus specimens using the compound microscope & 2.60 & ME \\
\hline Differentiate biotic from abiotic components of an ecosystem & 2.60 & ME \\
\hline Identify parts of the microscope and their functions & 2.49 & SE \\
\hline Describe the different levels of biological organization from cell to biosphere & 2.49 & SE \\
\hline $\begin{array}{l}\text { Differentiate plant and animal cells according to presence or absence of certain } \\
\text { organelles }\end{array}$ & 2.49 & SE \\
\hline Differentiate asexual from sexual reproduction & 2.46 & SE \\
\hline $\begin{array}{l}\text { Explain why the cell is considered the basic structural and functional unit of all } \\
\text { organisms }\end{array}$ & 2.43 & SE \\
\hline Identify beneficial and harmful microorganisms & 2.43 & SE \\
\hline Composite Mean & $\mathbf{2 . 5 5}$ & ME \\
\hline
\end{tabular}

Legend: WM=Weighted Mean $\quad$ VI= Verbal Interpretation $\quad$ ME= Moderate Extent $\quad \mathrm{SE}=$ Slight Extent 
As can be seen in the table, the teachers assessed that the competencies achieved by the students to a moderately extent on the different ecological relationships of an ecosystem and predicting the effect of changes in abiotic factors on the ecosystem. These competencies both obtained a weighted means of 2.66. The results revealed that explanations about ecosystem could be shared in appropriate doses enough to be processed by the students. As revealed by the science teachers during the interview, this topic is very interesting for the students. Teachers can provide different examples because the resources were very abundant. The teachers can give the actual example about ecosystem so that students can thoroughly understand the topic.

Focusing specimens using the compound microscope and differentiating biotic and abiotic components of an ecosystem were achieved by the students to a moderately extent as assessed by science teachers. This was justified by a weighted mean of 2.60. Many students nowadays understand the topic if they can really use the materials included in a specific topic. As revealed by the science teachers during the interview, it shows that students are lack of skills in the use of microscope. Different schools are really doing their best to supply the needs of the teachers and the students. It is very evident, because all schools have their own science laboratory where the microscopes are located. Students are using microscope, and they find it very interesting.

Explaining why cell is considered the basic structural and functional unit of all organisms and identifying beneficial and harmful microorganisms were achieved by the students to a slight extent as assessed by science teachers. This was justified by a weighted means of both 2.43 which ranked the least among the twelve items. As revealed by the science teachers during the interview, it shows that it is hard for the students to determine the unit of cells and harmful or beneficial microorganisms if they don't have the skills or knowledge to use different resources or equipment. They don't have enough resources to be able to understand this topic.

As a whole, the composite mean of 2.55 justified that the achieved learning competencies of the students in carrying activities in Biology were in moderately extent as assessed by the science teachers. It seems that the respondents believe that the students are taught science to enable them to understand science principles and facts to develop skills and processes of science investigations. This affirms Deboer ${ }^{[19]}$ statement that there is nothing wrong with teachers' as much as scientific content as they wish to, as long as that content is meaningful and comprehend and appreciate, not as life less abstractions.

\subsubsection{Chemistry}

Table 16 presents the mean distribution and verbal interpretation of assessment of the teachers in the achievable competencies of students in carrying out games in chemistry.

Table 16: Learning Competencies in Chemistry

\begin{tabular}{|l|l|l|}
\hline ITEMS & WM & VI \\
\hline Describe the components of a scientific investigation & 2.57 & ME \\
\hline Investigate properties of unsaturated or saturated solutions & 2.57 & ME \\
\hline $\begin{array}{l}\text { Recognize that substances are classified into elements and } \\
\text { compounds }\end{array}$ & 2.49 & SE \\
\hline
\end{tabular}




\begin{tabular}{|l|l|l|}
\hline $\begin{array}{l}\text { Describe some properties of metals and non-metals such as } \\
\text { luster, malleability, ductility, and conductivity }\end{array}$ & 2.49 & SE \\
\hline $\begin{array}{l}\text { Express concentrations of solutions quantitatively by } \\
\text { preparing different concentrations of mixtures according to } \\
\text { uses and availability of materials }\end{array}$ & 2.46 & SE \\
\hline $\begin{array}{l}\text { Investigate properties of acidic and basic mixtures using } \\
\text { natural indicators }\end{array}$ & 2.46 & SE \\
\hline $\begin{array}{l}\text { Distinguish mixtures from substances based on a set of } \\
\text { properties }\end{array}$ & 2.40 & SE \\
\hline Composite Mean VI= Verbal Interpretation ME= Moderate Extent & $\mathbf{2 . 4 9}$ & SE= Slight Extent \\
\hline
\end{tabular}

With weighted mean of both 2.49 , students achieved to slight extent the learning competencies in recognizing substances that are classified into elements and compounds and describing some properties of metals and non-metals such as luster, malleability, ductility, and conductivity. This means that the students were able to have an idea of the properties of elements and compound by knowing the materials related to them. As revealed by the science teachers during the interview, recognizing and describing the elements and compound were the interest of the students, it is because these topics are more on experimental. Students are very active when they are going to conduct an experiment. They can learn a lot from the experiment and they share to others what they have learned on that specific topics.

Likewise, the assessment of teachers in distinguishing mixtures from substance based on a set of properties was slightly extent as indicated in the obtained weighted mean of 2.40 . It shows that there are many opportunities for hands - on learning and more opportunities for practical application in science that students must achieved with.

To sum up, the composite mean of 2.49 justified that competencies in Chemistry were achieved by the students to a slight extent as assess by the science teachers. This means that the concepts they have learned in Chemistry as well as in other activities could practically be used in dealing with the changes since they have studied and exposed to these. This finding supports the recommendation of Abulude ${ }^{[20]}$ that provisions of enough exercises and practical work should be laid to arouse student's interest and understanding in the subject and to perform well in chemistry. 2. 4.4 Physics. The assessments of the teacher in the achieved competencies of the students in carrying out activities in Physics was presented in Table 17.

Table 17: Learning Competencies in Physics

\begin{tabular}{|l|c|c|}
\hline ITEMS & WM & VI \\
\hline Explain the importance of earthing or grounding & 2.63 & ME \\
\hline Describe the different types of charging processes & 2.57 & ME \\
\hline Infer that waves carry energy & 2.54 & ME \\
\hline $\begin{array}{l}\text { Differentiate transverse from longitudinal waves, and mechanical from } \\
\text { electromagnetic waves }\end{array}$ & 2.54 & ME \\
\hline $\begin{array}{l}\text { Describe the motion of an object in terms of distance or displacement, speed or } \\
\text { velocity, and acceleration }\end{array}$ & 2.51 & ME \\
\hline Differentiate quantities in terms of magnitude and direction & 2.51 & ME \\
\hline
\end{tabular}




\begin{tabular}{|l|l|l|}
\hline $\begin{array}{l}\text { Describe the characteristics of sound using the concepts of wavelength, velocity, } \\
\text { and amplitude }\end{array}$ & 2.51 & $\mathrm{ME}$ \\
\hline $\begin{array}{l}\text { Relate characteristics of light such as color and intensity to frequency and } \\
\text { wavelength }\end{array}$ & 2.51 & $\mathrm{ME}$ \\
\hline $\begin{array}{l}\text { Explain sound production in the human voice box, and how pitch, loudness, and } \\
\text { quality of sound vary from one person to another }\end{array}$ & 2.49 & $\mathrm{SE}$ \\
\hline $\begin{array}{l}\text { Describe how organisms produce, transmit, and receive sound of various } \\
\text { frequencies (infrasonic, audible, and ultrasonic sound) }\end{array}$ & 2.49 & $\mathrm{SE}$ \\
\hline Infer that light travels in a straight line & 2.49 & $\mathrm{SE}$ \\
\hline Infer the conditions necessary for heat transfer to occur & 2.49 & $\mathrm{SE}$ \\
\hline $\begin{array}{l}\text { Create and interpret visual representation of the motion of objects such as tape } \\
\text { charts and motion graphs }\end{array}$ & 2.46 & $\mathrm{SE}$ \\
\hline Relate the characteristics of waves & 2.43 & $\mathrm{SE}$ \\
\hline Composite Mean & $\mathbf{2 . 5 1}$ & $\mathrm{ME}$ \\
\hline
\end{tabular}

As presented in the table, the competency in explaining the importance of earthing or grounding was achieved by the students to a moderate extent as assessed by the science teachers. This obtained a weighted mean of 2.63 and obviously top on the list. This is clear indication that the students imbibe an ideal pattern of behavior such as explaining and developing scientific and systematic habits of work. This conforms with Reid ${ }^{[21]}$ idea that the higher the class level and the experience of the students, the more instructors can design the course toward greater freedom and individual discovery.

Similarly, inferring that waves carry energy and differentiating transverse from longitudinal waves, and mechanical from electromagnetic waves were achieved by the students to a moderate extent as assessed by the science teachers. These obtained the same weighted mean of 2.54 . This can be an indication that science teachers have to use different strategies in teaching different lesson emphasizing on the real - life application. This affirms Gere ${ }^{[22]}$ concept that experience of students is also effective way to learn science. Using experience approach, the students discover, create and figure out things.

Least rated and achieved by the students to slight extent is the competency relating the characteristics of waves. It is obtained by a weighted mean of 2.43 . This may be because the students are not interested with this topic, they feel bored while the teacher is discussing this topic.

The composite mean of 2.51 justified that the learning competencies in Physics are achieved by the students to a moderate extent. It is an indication that teachers are using different activities to supply knowledge for the students. They are actually giving their best in different experimentation and not more on with the concept. Teachers use hands - on activities for the student to gain knowledge in specific competency and they also give what the students need to be able to learn.

\subsection{Constraints Met in the Use of Game-Based Learning Activities}

The use of game - based learning activities is very important in providing opportunities for students to learn and be motivated in studying specific topic in science. Studying the constraints on the use of game - based learning activities in education may assist educators to overcome these 
barriers and become successful game user in the future. The constraints met in the integration of game - based learning activities in teaching science likewise part of the discussion in this study. They are presented in Table 18.

Table 18: Constraints in the Use of Game-based Learning Activities

\begin{tabular}{|l|c|c|}
\hline ITEMS & WM & VI \\
\hline Insufficient materials for the students & 3.46 & $\mathrm{~A}$ \\
\hline Individual differences of the students & 3.40 & $\mathrm{~A}$ \\
\hline Lack of trainings and seminars on the pedagogy of gaming & 3.37 & $\mathrm{~A}$ \\
\hline Lack of attention among students during explanation & 3.37 & $\mathrm{~A}$ \\
\hline Lack of cooperation among students & 3.34 & $\mathrm{~A}$ \\
\hline Inadequate skills and knowledge on the integration of games in the lesson & 3.31 & \\
& & $\mathrm{~A}$ \\
\hline Not enough space for the game - based activities & 3.29 & $\mathrm{~A}$ \\
\hline Weak internet connection needed in some of the online games & 3.26 & $\mathrm{~A}$ \\
\hline Inadequate facilities and equipment & 3.23 & $\mathrm{~A}$ \\
\hline Inadequate time to perform games & 3.20 & $\mathrm{~A}$ \\
\hline Negative attitudes concerning the use of games & 3.20 & $\mathrm{~A}$ \\
\hline Lack of definite lesson for which the activities are intended & 3.17 & $\mathrm{~A}$ \\
\hline Composite Mean & $\mathbf{3 . 3 0}$ & $\mathrm{A}$ \\
\hline
\end{tabular}

As contained in the table there were 12 identified problems that the teachers encountered in the use of game - based activities. Insufficient material for the students was encountered number one problem and is agreed by the teachers with a weighted mean of 3.46. The grade 7 science teachers noted that the materials to be used by the students not enough. There were instances when they have to spend their own money in providing materials individually.

Another problem encountered in the use of games which was agreed by the teachers was the individual differences of the students which obtained the weighted mean of 3.40. It is very hard for the teachers to use games if they don't know the capacity of the students in terms of academics. Lack of trainings and seminars on pedagogy of gaming and lack of attention among students during explanation were both obtained a weighted mean of 3.37. The result entails insufficient training due to the time for training, pedagogical training, skills training, and a game - based learning activities used in initial teacher training.

.The composite mean of 3.30 indicates that science teachers agreed that the problems listed above were met by grade 7 science teachers met problem in using games in teaching science lessons. The problems met by science teachers can be rooted from the new K-12 curriculum that was implemented in the country. Alongside with the implementation is needed adjustment not just for the curriculum developers but especially to the teachers and learners who are directly involved and affected with new curriculum. This finding is similar with the study of Contiguerra ${ }^{[23]}$, which revealed that teachers experienced serious problems in using games in a specific lesson. Game based learning activities resources need to be provided by the teachers or institutions. No one itself is sufficient to produce good teaching. 


\section{Conclusions}

Based on the findings of the study, the following conclusions are drawn:

1) Majority of science teachers are young female, single adults with a bachelor's degree.

2) Grade 7 science teachers utilize game - based learning activities to provide rich learning experiences for the students.

3) There is a significant difference in the description of game - based learning activities when respondents are grouped according to age but there is no significant difference in the description when they are grouped according to sex, civil status and educational attainment.

4) The learning competencies in earth science, biology, chemistry and physics are achieved by the students.

5) The constraints met by science teachers are insufficient materials and individual differences of the students.

\section{References}

[1] Killen, R., (2007). Teaching Strategies for Outcome - Based Education.

[2] Silberman, B.C., (2000). Taking stock: Where we've been, where we are, Where we're going. Journal of Women and Minorities in Science and Engineering, Vol. 8 No. 3\&4, pp. 255-284.

[3] Steele, J.E., (2007). Sociological perspectives on identity formation: the culture activities that Science teachers used. Journal of Adolescence, Vol. 19, pp. 417-428.

[4] Higgins, I. et.al., (2005). Guide to Simulations, Computer Games and Pedagogy in e - learning. Rex Book Store.

[5] Wexter, J.V.et.al., (2008). Grade 10 students perceptions of and attitudes towards science teaching and school science. Journal of Research in Science Teaching, 30, 175-186.

[6] Gee, M., (2003). Games - Makers to Empire. New York: Scholastic Press.

[7] Lazares, W. (2006). DOST Science and Technology Leads Philippines, Communication Resources and Production Division, Manila.

[8] Jonassen, J. (2008). The Process of Education, Cambridge, Mass: Harvard.

[9] Kooper, A., (2002). The approach of Game Activities. East Wood, Cartoon Books. Publishing.

[10] Thomberg, A. 2009. Educational psychology: Active learning edition. Ed. Ke-New Jersey: Pearson Education, Inc. Naple, Italy.

[11] Mift , D. D.M., (2003). Communicating in school science: groups, tasks, and problem solving 516, London, The Falmer Press.

[12] Jandonero, N.J., (2004). "The Appropriateness of Teaching Science and Students Achievement: A Basis for Intervention Enhancement," Master's Thesis, Lyceum of the Philippines - Laguna, Laguna.

[13] De Guzman, M. (2000). "The relevance of video games consoles to the higher and further education learning experience”, Master's Thesis College of Immaculate Conception, Cabanatuan City.

[14] Lardizabal, F. (2002). Principles and Method of Teaching. Mandaluyong City: National Bookstore.

[15] Tatlonghari, M. L. (2008). "Validation of the Learning Activity Package in Science IV." Master's Thesis, , Eulogio “Amang” Rodriguez Institute of Science and Technology, Nagtahan, Sampaloc Manila.

[16] Brunice, J., (2002). Programming and Media Technique, Manila: National Bookstore. 
[17] Carin, A., (2001). Teaching Science as Inquiry, Prentice-Hall Inc. Upper Saddle River New Jersey Columbus, Ohio.

[18] Kegan, H. M., (2002). Globalization and Its Impact on Education. Manila:Lorimar Publishing, Inc.

[19] Deboer, G., (2000). Scientific Literacy: Another look at its historical and Contemporary Meanings and its relationship to Science Education Reform, New York.

[20] Abulude, F. O., (2009). "Students' Attitude towards Chemistry in Some Secondary School in Akure South. Local Govt." Master's Thesis, Ondo State University.

[21] Reid, J. et.al., (2003). Teaching Thinking Skills: Theory and Practice, New York: Freeman.

[22] Gere, A., (2005). Best Practices and Strategies for Success, Portsmouth, NH: Heinemann.

[23] Contiguerra, Sharon (2005). " The Perceived Benefits Derived from the Use of Computers in Teaching the Public Secondary Schools of San Pascual District, Division of Batangas”, Master's Thesis, Batangas State University, Batangas City, Philippines

\footnotetext{
*Corresponding author.

E-mail address: olajiresola@yahoo.com
} 